\title{
PENERAPAN STRATEGI SENTENCE COLLECTION UNTUK MENINGKATKAN HASIL BELAJAR MENULIS TEKS EKSPLANASI
}

\author{
Budi Rahayu \\ SMA Negeri 7 Yogyakarta \\ budirahayusman7@gmail.com
}

\begin{abstract}
Abstrak: Penelitian ini merupakan Penelitian Tindakan Kelas (PTK) yang bertujuan untuk mengetahui strategi pembelajaran sentence collection dapat meningkatkan hasil belajar menulis teks eksplanasi peserta didik XI MIPA-2 SMA Negeri 7 Yogyakarta tahun pelajaran 2019/2020. Metode penelitian ini adalah cooperative learning dengan strategi sentence collection. Penelitian Tindakan Kelas (PTK) ini dilakukan dengan dua siklus. Setap siklus terdiri dari empat tahap, yaitu: a) persiapan, b) implementasi, c) observasi, dan d) refleksi. Teknik pengumpulan data menggunakan observasi dan tes kinerja. Instrumen pengumpulan data meliputi lembar pengamatan aktivitas guru, lembar penilaian sikap, dan instrumen penilaian teks eksplanasi. Analisis data menggunakan deskriptif kuantitaif untuk mengetahui peningkatan hasil kinerja peserta didik dalam mengikuti pembelajaran menggunakan strategi sentence collection. Hasil penelitian ini menunjukan bahwa pada prasiklus nilai rata-rata hanya 65,78, pada siklus 1 meningkat menjadi 76,75, dan pada siklus 2 meningkat menjadi 84,88 . Berdasarkan hasil tersebut dapat disimpulkan bahwa strategi pembelajaran sentence colection dapat meningkatkan hasil belajar menulis teks eksplanasi.
\end{abstract}

Kata kunci: sentence collection, hasil belajar, teks eksplanasi

\section{IMPLEMENTATION OF SENTENCE COLLECTION STRATEGY TO INCREASE WRITING EXPLANATION TEXT LEARNING OUTCOMES}

\begin{abstract}
This research is a Classroom Action Research (CAR) which aims to improve the writing explanation teks ability of students of Class XI MIPA-2 Yogyakarta 7 Public High School in 2019/2020. The purpose of this research was to prove whether sentence collection learning strategies could improve learning outcomes in writing explanatory text. The research used Classroom Action Research (CAR) method cooperative learning with sentence collection strategy. two cycles. Each cycle consisted of four stages, namely: a) preparation, b) implementation, c) observation, and d) reflection. Data collection techniques using observation and performance tests. Data collection instruments include teacher activity observation sheets, attitude assessment sheets, and explanatory text assessment instruments. Data analysis uses descriptive quantitative to determine the increase in learning outcomes of students in participating in learning using sentence collection strategies. The results of this study indicate that in the pre-cycle the average value is only 65.78 , in the first cycle increased to 76.75 , and in the second cycle increased to 84.88. Based on these results it can be concluded that sentence colectioan learning strategies could improve learning outcomes in writing explanatory texts.
\end{abstract}

Keywords: sentence collection strategy, learning outcome, explanatory text.

\section{PENDAHULUAN}

Pelajaran bahasa dan sastra Indonesia memiliki kecakapan pada membaca, berbicara, menyimak, serta menulis. Salah satu keterampilan yang harus dikuasai peserta didik adalah menulis. Pada umumnya peserta didik enggan menuangkan gagasannya secara tertulis. Peserta didik malas berpendapat, tidak kritis (apatis), serta rendah motivasi belajarnya, sehingga hasil belajar menulis menjadi rendah.

Kondisi ini diperparah dengan pendekatan pembelajaran bahasa Indonesia secara konvensional yang diterapkan oleh guru dalam proses pembelajaran. Pendekatan pembelajaran yang bersifat verbalistik serta konvensional.
Salah satu keterampilan yang harus dikuasai peserta didik adalah menulis. Ketika diberikan tugas menulis, untuk mengungkapkan idenya, peserta didik justru menggunakan gawai $(H P)$ untuk mengunduh tulisan dan menjadikannya sebagai hasil menulis. Peserta didik sering tidak mampu mengungkapkan gagasannya dengan benar. Implikasinya hasil belajar peserta didik pada mata pelajaran menulis tidak sesuai dengan yang diharapkan.

Peserta didik menganggap bahwa kemampuan berbahasa yang paling sulit penguasaannya adalah menulis, karena menulis adalah kegiatan yang memerlukan pengetahuan yang luas. 
Guru dapat mengetahui kemampuan menulis peserta didik dari hasil tulisan yang dibuat oleh peserta didik itu sendiri. Tulisannya kurang baik, sebab pengetahuan kebahasaannya memiliki banyak kesalahan kebahasaan mulai dari keruntutan logika berpikir, baik penggunaan tanda baca, maupun pemilihan diksi.

Peneliti mengadakan pre-test di kelas XI MIPA-2 SMA Negeri 7 Yogyakarta. Hasil pre-test berdasarkan wawancara dan observasi yang telah dilaksanakan memperlihatkan rendahnya hasil belajar siswa dalam memahami teks ekplanasi.

Rendahnya hasil belajar pada materi menulis teks eksplanasi peserta didik telah dibuktikan dengan adanya perolehan hasil pretest menulis teks eksplanasi dapat disimpulkan bahwa pada hasil pre-test diperoleh ketuntasan klasikal sebesar $50 \%$ dari 32 peserta didik yang berhasil mencapai nilai KKM pada predikat $\mathrm{B}+$ dan $\mathrm{B}$, dengan perolehan nilai rata-rata sebanyak 65,78 dan memperoleh predikat B-. Perolehan hasil tes tersebut dinyatakan belum berhasil karena belum mencapai target ketuntasan secara klasikal sebesar $85 \%$ dan nilai rata-rata hasil tes tersebut belum mencapai nilai KKM 75 .

Berdasarkan latar belakang di atas maka dirumuskan masalah sebagai berikut pertama, bagaimana proses pembelajaran menulis teks eksplanasi peserta didik kelas XI MIPA-2 SMA Negeri 7 Yogyakarta dengan menggunakan strategi Sentence Collection? Kedua, bagaimana peningkatan hasil belajar menulis teks eksplanasi peserta didik kelas XI MIPA-2 SMA Negeri 7 Yogyakarta setelah mengikuti kegiatan pembelajaran dengan menggunakan strategi Sentence Collection?

Adapun tujuan yang hendak dicapai dari penelitian ini adalah untuk mengetahui apakah strategi pembelajaran sentence collection dapat meningkatkan hasil belajar menulis teks eksplanasi peserta didik XI MIPA-2 SMA Negeri 7 Yogyakarta tahun pelajaran 2019/2020.

Pembelajaran bahasa memiliki empat aspek keterampilan yang harus dimiliki yaitu keterampilan menyimak, keterampilan berbicara, keterampilan membaca, dan keterampilan menulis (Tarigan, 2008:1). Menulis merupakan suatu kegiatan berkomunikasi (Effendi, 2008:327; Dalman, 2014:3) dalam bentuk penyampaian pesan secara tertulis kepada pihak lain (Tarigan, 2008:3).
Sukirno (2010: 6) menyatakan bahwa menulis sangat bermanfaat bagi peserta didik untuk mengungkapkan pikiran dan perasaaan secara tertulis sehingga diketahui oleh orang lain, dapat bekerja sama mengenal adat istiadat, dan tata krama masyarakat. Artinya, setiap ide atau gagasan yang ada dalam fikiran manusia dapat dituangkan melalui sebuah tulisan sehingga orang lain yang membacanya akan mengetahui ide atau gagasan yang ada dalam fikiran manusia tersebut melalui tulisan. Menurut iskandarwassid (2011: 250), kriteria yang digunakan dalam penilaian keterampilan menulis antara lain: 1) kesesuaian judul degan isi tulisan, 2) ketepatan penggunaan gaya bahasa, ejaan, dan tanda baca, 3) kesatuan, kepaduan, dan kelengkapan dalam setiap paragraf, 4) jelas, 5) kohesi, dan 6) koherensi.

James Britton dalam bukunya Language and Learning (Campbell, 2006: 3) membuat kategori menulis dengan menawarkan pandangan bagi guru mengenai jenis karya tulis yang diberikan pada peserta didik diantaranya: 1) kategori pertama, pemakaian kegiatan menulis secara mekanis seperti latihan pilihan ganda dan transkip dari bahan oral, 2) kategori kedua, meliputi penggunaan kegiatan menulis untuk keperluan personal seperti diary dan jurnal, 3) kategori ketiga, penggunaan kegiatan menulis imaginative seperti cerita atau puisi, dan 4) kategori keempat, berhubungan dengan penggunaannya informasi seperti membuat catatan, mencatat pengalaman dalam bentuk laporan, ringkasan, analisis, teori, atau tulisan eksplanasi,

Teks eksplanasi adalah teks yang berisi penjelasan tentang proses terjadinya atau terbentuknya suatu fenomena alam atau sosial (Pardiyono, 2007: 155), ilmu budaya, dan yang lainnya (Priyatni, 2014: 83). Sebuah teks eksplanasi berasal dari pertanyaan terkait mengapa dan bagaimana suatu peristiwa bisa terjadi (Knapp \& Watkins, 2005: 126). Senada dengan pendapat tersebut Kosasih (2013: 85) mengungkapkan bahwa teks eksplanasi merupakan teks yang menerangkan atau menjelaskan mengenai proses atau fenomena alam dan sosial.

Menurut Mulyadi (2014: 176) hal yang harus diingat dalam isi teks eksplanasi adalah menjelaskan sesuatu hal yang berangkat dari fakta untuk kemudian menghasilkan kesimpulan umum agar pembaca menyetujui 
pendapat dan sikapnya. Secara garis besar dalam teks eksplanasi mengandung 3 unsur penting, yaitu: 1) a general statemen about the even or thing (suatu pernyataan umum tentang peristiwa atau benda), 2) a series of paragraphs that tell the hows and why ( suatu rangkaian dari paragraf yang berisi menceritakan bagaimana dan mengapa suatu peristiwa itu terjadi), 3) a concluding paragraf (penutup paragraf dari suatu teks eksplanasi yang berisi simpulan) (Andreson (1997: 82; Pardiyono, 2007: 156). Teks eksplanasi umumnya memerlukan kata sambung yang bergabung dengan kata kerja sehingga secara logis menunjukan sebab akibat (Knaap \& Watkins, 2005: 126; Priyatni et al, 2014: 135).

Ketika kita akan menyusun sebuah teks, tentunya kita memerlukan pengetahuan tentang bagaimana langkah-langkah yang harus dilakukan agar dapat menyusun sebuah teks yang baik dan benar. Menulis teks eksplanasi menurut Priyani et al (2014: 126132) terdiri dari beberapa langkah sebagai berikut: 1) memilih topik yang menjelaskan bagaimana dan mengapa peristiwa atau fenomena terjadi, 2) memulai tulisan dengan pernyataan umum yang memuat petunjuk awal suatu peristiwa, rangkaian penjelasan yang memuat bagaimana dan mengapa suatu peristiwa terjadi, dan penutup berupa simpulan atau pengulangan informasi penting, 3) melakukan telaah dan revisi atas tulisan yang dibuat, dan 4) melakukan pengamatan atau studi pustaka agar tulisan dapat dipertanggung jawabkan secara ilmiah.

Pada jenjang SMA kelas XI, menulis teks eksplanasi merupakan salah satu kompetensi yang harus dicapai oleh peserta didik. Keterampilan menulis teks eksplanasi secara tertulis menuntut peserta didik untuk dapat mengungkapkan dan mengembangkan gagasannya, terhadap fenomena atau permasalahan yang terjadi di lingkungan sekitar, kemudian diamati dan dituliskan dalam bentuk teks eksplanasi, sehingga pengetahuan, daya pikir, dan kreativitas peserta didik dapat meningkat. Akan tetapi, hasil belajar dalam proses pembelajaran Bahasa Indonesia mengenai materi menulis teks eksplanasi masih rendah. Hal ini dibuktikan dengan perolehan hasil belajar menulis teks eksplanasi kelas XI MIPA 2 SMA Negeri 7 Yogyakarta yang hanya memperoleh ketuntasan klasikal sebesar 50\% dari 32 peserta didik yang berhasil mencapai nilai KKM pada predikat $\mathrm{B}+$ dan $\mathrm{B}$, dengan perolehan nilai rata-rata sebanyak 65,78 dan memperoleh predikat B-. Perolehan hasil tes tersebut dinyatakan belum berhasil karena belum mencapai target ketuntasan secara klasikal sebesar $85 \%$ dan nilai rata-rata hasil tes tersebut belum mencapai nilai KKM 75 .

Rendahnya hasil belajar menulis teks eksplanasi disebabkan karena peserta didik enggan menuangkan gagasannya secara tertulis. Peserta didik malas berpendapat, tidak kritis (apatis), serta rendah motivasi belajarnya, sehingga menjadikan hasil belajar menulis menjadi rendah. Fakta tersebut dibuktikan dengan hasil wawancara yang dilakukan peneliti terhadap beberapa pendidik yang menaungi pembelajaran Bahasa Indonesia di SMA N 7 Yogyakarta. Pada proses wawancara tersebut dapat disimpulkan faktor-faktor yang menyebabkan rendahnya kemampuan menulis teks eksplanasi peserta didik, yaitu: 1) minat belajar peserta didik masih kurang dan cenderung bosan pada saat mengikuti kegiatan pembelajaran, 2) peserta didik kurang konsentrasi dalam menerima pelajaran, 3) peserta didik kurang memahami materi tentang menulis teks eksplanasi, sehingga sulit membedakan dengan jenis teks yang lain, 4) peserta didik kesulitan mengembangkan gagasan, dan 5) peserta didik masih belum bisa menggunakan bagaimana penulisan yang baik dan benar dari segi ejaan, tanda baca, dan pilihan kata.

Berbagai faktor yang menyebabkan rendahnya hasil belajar teks eksplanasi tersebut sebenarnya dapat diatasi jika guru menerapkan model/strategi pembelajaran yang efektif dalam membangkitkan minat belajar peserta didik. Pembelajaran efektif dan produktif adalah kegiatan pembelajaran yang secara terencana membantu peserta didik mencapai dua tujuan utama, yakni mencapai tujuan pembelajaran secara optimal dan sekaligus mengkondisikan peserta didik produktif dalam menghasilkan gagasan-gagasan (Suyono, 2014). Berdasarkan berbagai hal tersebut, peneliti berusaha untuk mengatasi kesulitan-kesulitan yang dialami peserta didik dalam menulis teks eksplanasi dengan menggunakan strategi sentence collection.

Strategi sentence collection merupakan strategi yang dikembangkan oleh Speker (1991) yang bertujuan untuk meningkatkan 
kemampuan pemahaman peserta didik dan kemampuan menulis kalimat kompleks serta untuk membantu peserta didik meningkatkan berpikir tingkat tinggi. Dalam strategi ini peserta didik berperan sebagai peserta aktif dan membangun kepercayaan dengan memperlihatkan koleksi kalimat mereka di dalam kelas supaya dilihat oleh temannya. Peserta didik mendiskusikan kalimat itu dengan teman sekelasnya. Strategi ini mendorong keterkaitan antara keterampilan membaca dan menulis dalam pembelajaran di kelas (Wiesendanger, 2001).

Langkah pertama yang dilakukan dalam menerapkan strategi sentence collection adalah mengenalkan kepada peserta didik kalimat kreatif yang ditemukan di dalam teks eksplanasi. Kalimat-kalimat ini dapat berisi tentang kosa kata, nada cerita, membandingkan karakter dan menjelaskan plot. Setelah peserta didik menemukan kalimat kreatif pada teks eksplanasi, selanjutnya kalimat-kalimat tersebut ditulis pada kertas berwarna untuk didiskusikan agar dapat mendorong peserta didik untuk menambah kalimat mereka sendiri. Pada proses ini, pembelajaran dapat difokuskan pada pola kalimat tertentu yang dipilih untuk meningkatkan penguasaan struktur kalimat tersebut. Langkat terakhir yang dilakukan adalah menampilkan kalimat-kalimat tersebut di depan kelas. Luangkan waktu setiap pertemuan untuk membahas kalimat-kalimat itu dan menambah koleksi kalimatnya agar menjadi sebuah teks eksplanasi yang utuh.

Pembelajaran menulis teks eksplanasi dengan menggunakan strategi sentence collection, diharapkan dapat menarik, memotivasi, mengenalkan atau menunjukkan kepada peserta didik dalam memahami materi menulis teks eksplanasi, sehingga hasil belajar menulis teks eksplanasi peserta didik kelas XI MIPA-2 SMA Negeri 7 Yogyakarta akan meningkat.

\section{METODE PENELITIAN Jenis Penelitian}

Jenis penelitian ini adalah penelitian kualitaif yaitu Penelitian Tindakan Kelas (PTK) yang terdiri dari tiga siklus. Desain siklus dalam penelitian ini menggunakan model Kemmis yang terdiri dari persiapan, pelaksanaan, observasi, dan refleksi (Arikunto, 2012).

\section{Waktu dan Tempat Penelitian}

Waktu penelitian dilaksanakan dari bulan Agustus hingga Oktober tahun 2019. Tempat penelitian di SMA Negeri 7 Yogyakarta, jalan MT Haryono 47 Yogyakarta 55141.

\section{Subjek Penelitian}

Pemilihan subjek penelitian berdasarkan purposive sampling, dimana subjek penelitian ditentukan berdasarkan nilai rata-rata setiap kelas yang mempunyai nilai keterampilan menulis ulasan teks eksplanasi yang paling rendah. Berdasarkan hasil penilaian pretest didapatkan nilai rata-rata kelas paling rendah adalah XI MIPA 2 dengan ketuntasan klasikal sebesar $50 \%$ dari 32 peserta didik yang berhasil mencapai nilai KKM pada predikat $\mathrm{B}+$ dan $\mathrm{B}$, dengan perolehan nilai rata-rata sebanyak 65,78 dan memperoleh predikat B-.

Data, Intrumen, dan Teknik Pengumpulan Data

Pengambilan data penelitian melalui test dan non test. Tes yang digunakan dalam penelitian ini berupa tes perbuatan. Tes perbuatan adalah tes bahasa yang menghendaki jawaban peserta tes dalam bentuk penampilan/perbuatan atau kinerja (Wahyuni \& Ibrahim, 2012: 11). Teknik tes dilakukan secara individu melalui unjuk kerja menulis teks eksplanasi dengan instrumen berupa pedoman penilaian unjuk kerja yang berbentuk daftar checklist. Sedangkan teknik non test digunakan melalui metode observasi untuk mengetahui perubahan perilaku peserta didik dengan instrumen lembar penilaian sikap menggunakan skala likert dan tanggapan peserta didik terhadap pelaksanaan kegiatan pembelajaran dengan instrumen tanggapan peserta didik menggunakan skala guttman.

\section{Teknik Analisis Data}

Teknik analisis data yang digunakan dalam penelitian ini adalah teknik analisis data secara kualitatif dan teknik analisis data secara kuantitatif. Pelaksanaan analisis data kualitatif dilakukan melalui empat tahapan, yaitu persiapan, pengelompokan data, penyajian data, dan penyimpulan data. Pada tahap perencanaan peneliti melakukan pengecekan data yang bersumber dari data hasil wawancara, catatan lapangan, dan lembar observasi. Tahap pengumpulan data dilakukan dengan menyusun pola-pola tertentu dari data yang telah diperoleh. Pada tahap ini, data yang berupa hasil wawancara, catatan lapangan, dan 
lembar observasi disusun berdasarkan pola tertentu yang dapat merangkum pertanyaan yang diperlukan untuk menjawab masalah penelitian. Data dari hasil kegiatan analisis disajikan dalam klasifikasi berdasarkan kriteria-kriteria tertentu, sehingga memberikan gambaran yang mengarah pada pemerolehan jawaban atas masalah penelitian. Evaluasi terhadap peningkatan kemampuan menulis teks eksplanasi peserta didik. Kegiatan yang dilakukkan adalah menginterprestasi data untuk menghasilkan suatu temuan. Kegiatan meyimpulkan kemudian diikuti dengan triangulasi yang dilakukkan dengan meninjau kembali temuan melalui bertukar pikiran dengan teman sejawat.

Analisis data kuantitatif dilakukan dengan cara menghitung data berdasarkan hasil penelitian yang diperoleh dari hasil tes peserta didik. Hasil perhitungan nilai tes kemudian dianalisis untuk mengetahui perubahan kemampuan peserta didik pada setiap siklus. Nilai pembelajaran menulis teks eksplanasi dengan menggunakan strategi sentence collection dibandingkan dengan perolehan nilai pada prasiklus, untuk mengetahui apakah ada peningkatan kemampuan peserta didik atau tidak. Dinyatakan ada peningkatan apabila peserta didik berhasil mencapai target yang telah ditetapkan. Nilai ketuntasan ditargetkan untuk dapat meraih ketuntasan sebanyak $85 \%$ dari nilai keseluruhan peserta didik, dengan nilai KKM minimal 75. Setelah mengetahui nilai masing-masing peserta didik, nilai dijumlah untuk dijadikan presentase ketuntasan dan rata-rata nilai dalam satu kelas tersebut. Rumus yang digunakan untuk menetukan nilai rata-rata adalah:

$$
\mathrm{M}=\frac{\Sigma x}{N}
$$

Keterangan:

$\mathrm{M}=$ mean (rata-rata)

$\mathrm{X}=$ jumlah skor

$\mathrm{N}=$ jumlah peserta didik

\section{HASIL DAN PEMBAHASAN}

Pada kondisi awal, keterampilan menulis puisi peserta didik masih rendah, peserta didik masih banyak yang memperoleh nilai di bawah $\mathrm{KKM} \leq 75$. Hal ini dibuktikan dengan hasil nilai pratindakan dengan 32 peserta didik hanya 16 peserta didik yang mendapat nilai lebih dari $\mathrm{KKM} \geq 75$ pada predikat $\mathrm{B}+$ dan $\mathrm{B}$ dengan perolehan nilai rata-rata 65,78 , sedangkan 16 peserta didik lainnya masih dibawah KKM (lihat tabel 1.).

Tabel 1. Distribusi Data Nilai Menulis Teks Eksplanasi Prasiklus

\begin{tabular}{cc}
\hline Keterangan & Hasil \\
\hline Tuntas & 16 orang $(50 \%)$ \\
Belum Tuntas & 16 orang $(50 \%)$ \\
Nilai Tertinggi & 80,00 \\
Nilai Terendah & 45,00 \\
Rata-Rata & 65,78 \\
\hline
\end{tabular}

Pelaksanaan pembelajaran menulis teks eksplanasi menggunakan strategi Sentence Collection pada siklus I dilakukan pada hari Selasa tanggal 10 September 2019 jam ke 1 dan 2, dilanjuktan pada pertemuan ke dua hari Rabu tanggal 11 September 2019 pada jam ke 3 dan 4 di kelas XI MIPA-2 SMA Negeri 7 Yogyakarta. Pembelajaran dilaksanakan berdasarkan skenario pembelajaran yang telah dibuat dan disepakati oleh penulis dan kolaborator pada tahap perencanaan.

Nilai hasil belajar keterampilan menulis teks eksplanasi pada siklus satu (lihat tabel 2.) mengalami peningkatan. Hasil tersebut menunjukan bahwa terdapat 24 orang yang mencapai kriteria ketuntasan, atau sekitar $75 \%$ dan ada 8 orang yang belum mencapai kriteria ketuntasan atau sekitar $25 \%$ dengan nilai tertinggi 90 dan nilai terendah 60 dengan perolehan nilai rata-rata sebesar 76,75. Persentase hasil belajar menulis teks eksplanasi pada siklus satu sudah termasuk ke dalam kriteria baik, akan tetapi belum mencapai target minimal ketuntasan yang ditentukan. Oleh karena itu, penelitian perlu dilanjutkan ke siklus dua.

Tabel 2. Distribusi Data Nilai Menulis Teks Eksplanasi Siklus Satu

\begin{tabular}{cc}
\hline Keterangan & Hasil \\
\hline Tuntas & 24 orang $(75 \%)$ \\
Belum Tuntas & 8 orang $(25 \%)$ \\
Nilai Tertinggi & 90,00 \\
Nilai Terendah & 60,00 \\
Rata-Rata & 76,75 \\
\hline
\end{tabular}

Selain melakukan penilaian hasil belajar, peneliti juga melakukan pengamatan proses pembelajaran guna mengetahui minat belajar peserta didik ketika mengikuti pembelajaran menggunakan strategi sentence collection. Berdasarkan pengamatan yang telah 
dilaksanakan secara garis besar pada siklus dua dapat disimpulkan bahwa minat peserta didik mengalami peningkatan dalam proses pembelajaran menulis teks eksplanasi menggunakan strategi sentence collection. Peserta didik sudah mulai berani bertanya dan menjawab pertanyaan dari guru. Mereka tidak lagi malu-malu bertanya kepada guru ketika mengalami kesulitan saat menulis teks eksplanasi. Ketika guru membagikan teks eksplanasi, peserta didik terlihat antusias membaca dan mendiskusikan isi teks eksplanasi tersebut bersama rekan satu kelompoknya.

Setelah mengetahui hasil belajar dalam pembelajaran menulis teks eksplanasi menggunakan strategi sentence collection, peneliti bersama observer melakukan kegiatan refleksi untuk mengkaji dan mengevaluasi seluruh kegiatan yang telah berlangsung selama siklus satu dilakukan. Evaluasi ini digunakan untuk merencanakan perbaikan yang akan dilakukan pada tindakan siklus dua.

Tabel 3. Hasil Refleksi Siklus Satu

\begin{tabular}{ll}
\hline \multicolumn{2}{c}{ Hasil Refleksi Siklus Satu } \\
$\begin{array}{l}\text { Ketika mengajar guru hanya di depan kelas } \\
\text { saja }\end{array}$ & $\begin{array}{l}\text { Pada pertemuan selanjutnya guru dapat berkeliling untuk } \\
\text { memantau peserta didik secara keseluruhan sehingga peserta didik } \\
\text { akan lebih aktif dan termotivasi untuk semangat belajar karena } \\
\text { guru mempunyai rasa peduli yang tinggi, }\end{array}$ \\
$\begin{array}{l}\text { Belum maksimalnya guru dalam } \\
\text { menyampaikan materi pembelajaran }\end{array}$ & $\begin{array}{l}\text { Pada pertemuan selanjutnya guru lebih detail dan lebih banyak } \\
\text { memberi contoh konkret kepada peserta didik sehingga peserta } \\
\text { didik lebih mudah memahami materi tersebut fokus. }\end{array}$ \\
$\begin{array}{l}\text { Hasil produk peserta didik masih belum } \\
\text { sempurna }\end{array}$ & $\begin{array}{l}\text { Aspek yang perlu diperbaiki antara lain; isi, struktur teks, dan } \\
\text { tandabaca. }\end{array}$ \\
\hline
\end{tabular}

Berdasarkan data tersebut, diperoleh informasi bahwa setelah dilakukan observasi dan refleksi pada siklus satu, kemudian disusun rencana yang akan dilakukan pada siklus dua. Berdasarkan pengamatan di lapangan, dari hasil perbaikan yang dilakukan menunjukan pembelajaran pada siklus dua berjalan lebih baik. Pada penyampaian materi yang dilakukan guru kepada peserta didik juga lebih detail dan lebih banyak memberikan contoh, sehingga peserta didik lebih mudah memahami materi tersebut. Pelaksanaan pembelajaran menulis teks eksplanasi menggunakan strategi Sentence Collection pada siklus II dilakukan pada hari Selasa, tanggal 24 September 2019 pada jam ke 1 dan 2 serta pada hari Rabu, tanggal 25 September 2019 pada jam ke 3 dan 4 di kelas XI MIPA-2 SMA Negeri 7 Yogyakarta. Pembelajaran dilaksanakan berdasarkan skenario pembelajaran yang telah dibuat dan disepakati oleh penulis dan guru pada tahap perencanaan. Pertama, guru melakukan presensi, menjelaskan tujuan pembelajaran, menyampaikan evaluasi dari hasil menulis teks eksplanasi pada tahap prasiklus, dan memotivasi peserta didik agar peserta didik berminat mengikuti pembelajaran.

Pada kegiatan inti guru mengulas kembali materi tentang teks eksplanasi. Kali ini guru menggunakan pertanyaan untuk membantu mengingatakan peserta didik tentang materi teks eksplanasi. Selain itu, guru juga lebih sering memberi contoh konkret. Dalam proses pembelajaran, peserta didik terlihat senang mengikuti pembelajaran pada siklus II. Dari hasil tndakan Siklus II didapat hasil sebagai berikut:

Tabel 4. Distribusi Data Nilai Menulis Teks Eksplanasi Siklus Dua

\begin{tabular}{cc}
\hline Keterangan & Hasil \\
\hline Tuntas & 32 orang $(100 \%)$ \\
Belum Tuntas & 0 orang \\
Nilai Tertinggi & 100,00 \\
Nilai Terendah & 75,00 \\
Rata-Rata & 84,88 \\
\hline
\end{tabular}

Proses pembelajaran pada Siklus II ini, peserta didik terlihat senang. Hasil belajar menunjukan ada kenaikan dengan kriteria ketuntasan sebesar $100 \%$ dari 32 peserta didik. Hal ini disebabkan karena pada proses pembelajaran siklus dua mengalami perubahan pola pengajaran yang dilakukan oleh guru yang mengakibatkan meningkatnya tingkat pemahaman peserta didik. Peningkatan konsep pemahaman peserta didik mengenai keterampilan menulis teks eksplanasi menyebabkan proses pembelajaran di dalam kelas lebih efisien. 
Selain melakukan penilaian hasil belajar, peneliti juga melakukan pengamatan proses pembelajaran guna mengetahui minat belajar peserta didik ketika mengikuti pembelajaran menggunakan strategi sentence collection. Berdasarkan pengamatan yang telah dilaksanakan secara garis besar pada siklus dua dapat disimpulkan bahwa minat peserta didik mengalami peningkatan dalam proses pembelajaran menulis teks eksplanasi menggunakan strategi sentence collection. Peserta didik sudah mulai berani bertanya dan menjawab pertanyaan dari guru. Ketika guru membagikan teks eksplanasi, peserta didik terlihat antusias membaca dan mendiskusikan isi teks eksplanasi tersebut bersama rekan satu kelompoknya.

Berdasarkan hasil di atas dapat digambarkan proses peningkatan hasil belajar peserta didik dari proses prasiklus, siklus I, dan siklus II pada diagram di bawah ini:

\section{Ketuntasan Hasil Belajar}

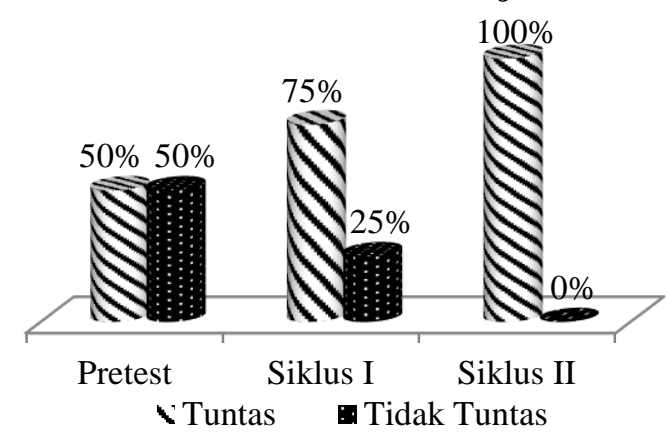

Gambar 1. Diagram Persentase Peningkatan Hasil Belajar Menulis Teks Eksplanasi

\section{Peningkatan Nilai Rata-Rata}



Gambar 2. Diagram Peningkatan Perolehan Nilai Rata-Rata

\section{SIMPULAN}

Berdasarkan hasil penelitian dapat disimpulkan bahwa penerepan strategi sentence collection dapat meningkatkan keterampilan menulis teks eksplanasi pada peserta didik kelas XI MIPA 2 SMA N 7 Yogyakarta tahun pelajaran 2018/2019.
Sebelum dilakukan penelitian, pesersentase ketuntasan keterampilan menulis teks eksplanasi hanya mencaau $50 \%$ dari 32 peserta didik. Setelah dilakukanya tindakan pada siklus satu, persentase ketuntasan peserta didik meningkat menjadi $75 \%$. Karena target pencapaian yang diinginkan adalah $85 \%$ ketuntasan, oleh sebab itu, penelitian dilanjutkan pada tindakan siklus dua. Setelah dilaksanakan tindakan pada siklus dua, hasil persentase ketuntasan keterampilan teks eksplanasi meningkat menjadi $100 \%$.

Dari segi perolehan rata-rata sebelum dilakukanya tindakan (pretest) didapatkan nilai rata-rata sebesar 65,78. Setelah diterapkannya strategi sentence collection dalam pembelajaran menulis teks eksplanasi, nilai rata-rata peserta didik meningkat menjadi 76,75 pada siklus satu, dan meningkat lagi menjadi 84,88 pada siklus dua.

Dari hasil tersebut dapat disimpulkan bahwa strategi pembelajaran sentence collection dapat meningkatkan hasil belajar keterampilan menulis teks eksplanasi peserta didik kelas XI MIPA 2 SMA Negeri 7 Yogyakarta.

\section{DAFTAR PUSTAKA}

Anderson, Mark., \& Kathy Anderson. (1997). Text types in english. Malaysia: Macmillan Education Australia.

Arikunto, Suharsimi., (2014). Penelitian tindakan kelas. Jakarta: Bumi Aksara.

Campbell, Linda., Campbell, Bruce., \& Dickinson, Dee. (2006). Metode praktis pembelajaran berbasis multiple intelligences. Depok: Intuisi Press.

Dalman, H. (2012). Keterampilan menulis. Jakarta: PT Raja Grafindo Persada.

Effendy, O. U. (2008). Dinamika komunikasi. Bandung: PT Remaja Rosdakarya.

Iskandarwassid., \& Sunendar, Dadang. (2011). Strategi pembelajaran bahasa. Bandung: Remaja Rosdakarya.

Kosasih, E., \& Restuti. (2013). Mandiri bahasa Indonesia. Jakarta: Erlangga.

Tarigan., \& Hendri Guntur. (2008). Menulis sebagai suatu keterampilan berbahsa. Bandung: Angkasa.

Priyatni, E. T. (2014). Desain pembelajaran bahasa indonesia dalam kurikulum 2013. Jakarta: Bumi Aksara. 